\title{
Fretting Damageについて
}

高橋 達* 岸本秀弘** 酒井 瞳***

\section{1. ま えがき}

接触面が微小な往復相対運動（たとえば $0.01 \mathrm{~mm}$ )を 行ならと, その面が擵耗し, 亀裂の発生が促進される。 この現象を fretting という. fretting の発生する具体的 な機械部品としては圧入軸, 焼ばめ軸, リベット継手, 重ね板ばね，ころがり軸受などの例をあげることができ る. frettingはこれらの部品の疲労強度の低下, 摩耗に よる寸法精度の低下などを誘起し工学的に大きな問題を 提起して和り, 摩耗, 疲労比関する研究分野で実験研究 がなされているが，その機構は明らかでない。

この総説は過去に発表された論文をもとにして摩耗の 立場からみた fretting に上る被害と, 疲労強度の立場か らみた fretting による被害についてまとめてみたもの で, fretting に関する実験的研究結果を中心炕して話し をすすめ, fretting に影響を蛙よぼす要因, 機構, 被害の 防止方法について述べ, fretting について少しでる筋の と招つた見方ができるように心が忛た。

な扮, fretting 現象は fretting corrosion, chafing fatigue, 微動摩耗などとも表現されているがここでは fretting 起因する疲労被害を fretting fatigue と呼び, fretting の結果生ずる摩耗を fretting wear と呼ぶこと にする。

\section{2. fretting に 影 響 を およぼす要 因}

fretting は材料の硬度, 接螌応力, 雾囲気などによつ て影響をうけることが知られている。 以下にそれらの影 響について述べる。

\section{(1) 硬 度の影響}

鋳鉄で行なつた Wright(1)の fretting wear そ関する実 験結果によると乾燥条件下では体積摩耗量 $V$ は硬度 $H$ (硬度 Hv 100 250) とV $V \propto H^{-2.5}$ の関係にあり, 潤滑条

* トヨタ自動車工業株式会社第 2 技術部強度実験課 課長

** ト ヨ夕自動車工業株式会社第 2 技術部強度実験課 係長

****ヨタ自動車工業株式会社第 2 技術部強度実験課

(1) K.H.R.Wright: Proc. Conf. on Lub. and Wear, (1957) ,628.
件下では $V \propto H^{-1}$ の関係にある。 McDowell(2)は AISI 4340 鋼での 実験結果により 硬度範囲が Hv 250 450で は硬度の影響が汇とんどないが窒化 (硬度 Hv 743) によ る効果はすることを認めている。また軸受鋼について行 なつた伊藤(3)の実験結果によると, Hv 544 の材料は Hv 832 の材料より $70 \%$ 摩耗量が多い.これらの事実は一般 摩耗けに関して,われわれがしばしば経験する傾向とも一 致しておうう,Holm の理論や Oberle の Modell は fretting wear と硬度に関する実験式を得るための大きな手がか りになるとも考えられる。ただ fretting wear ではすべ り振巾が非常に小さく摩耗粉が散逸しにくいため摩耗粉 の堆積効果により一般摩耗とは違つた摩耗条件にあるこ とに注意する必要がある。

材料の硬度ではないが摩耗粉の堆積效果に関連して摩 耗粉の硬度の影響について簡単に述べておく. Fenner, Wright 括よび Mann(4) は相手材料を種々選び 鋼の摩耗 量を測定しているが，その結果によると鋼の摩耗量は相 手材料にほとんど依存しない。たとえばアルミニウム対 鋼と亜鉛対鋼の組合わせで摩耗量を測定すると両組合わ せとも鋼の摩耗量は, 鋼対鋼の摩耗量とほぼ一致してい る. 参考にこれらの Mohs 硬度をあげるとアルミニウム 2 , 酸化アルミニウム 9 , 覀鉛 2.5 , 酸化亜鉛 4 , 鋼 7 , 酸化鉄 5.5 である。この結果から判断すると摩耗粉の硬 度はあまり大きな影響がないようにも見らけられるが， Fenner(4)らが指摘しているように, 鋼から発生した摩耗 粉が相手材から生じた摩耗粉と鋼の接触を妨げたとも解 釈できる。したがつてすべり振巾が大きくなれば相手材 の摩耗粉の影響もでてくると考学られる。 Dies(5) が摩耗 粉の硬度が影響するという結果を得たのも摩耗粉が互い に混合するほどのすべり振巾であつたと考光るべきであ るかもしれない。また Sakmann と Rightmire(6) は材料

(2) J.R.McDowe11: ASLE Trans., 1 (1958) ,287.

(3) 伊藤：日本機械学会誌, 62 (1959), 410 .

$\dagger$ 以下 fretting wear のよ5に微小振门の往復運動 の結果生ずる摩耗に対し，一方向すべり運動もし くは大振巾の往復運動により生ずる摩耗を一般摩 耗といらことにする。

(4) A.J.Fenner, K.H.R.Wright and J. Y. Mann: Int. Conf. on Fatigue of Metals, (1956) , 386.

(5) K.Dies: The Engineers Digest,2 (1945), 14.

(6) B. W. Sakmann and B. G. Rightmire : NACA Tech. Note, No.1492, (1948) . 
が硬くしかも摩耗粉の硬い場合には摩耗量が多くなると 述べている. 以上の摩耗粉の効果に関する結果からも推 察できるように異種金属同志で fretting wearを生ぜし めたとき，すべり振巾の大ささいかんによつて摩耗量が 相手材の摩耗粉の影響をうける場合とうけない場合があ り, 単に両者の硬度および両摩耗粉の硬度だけで摩耗量 を整理するのは妥当でないことがわかる。

つぎに fretting fatigue と硬度の関係について述べる. Liu, Corten 执よび Sinclair(7) は固定材料を種々にかえ たチタン合金の平面曲げ疲労試験を行なつた。簈 1 図は

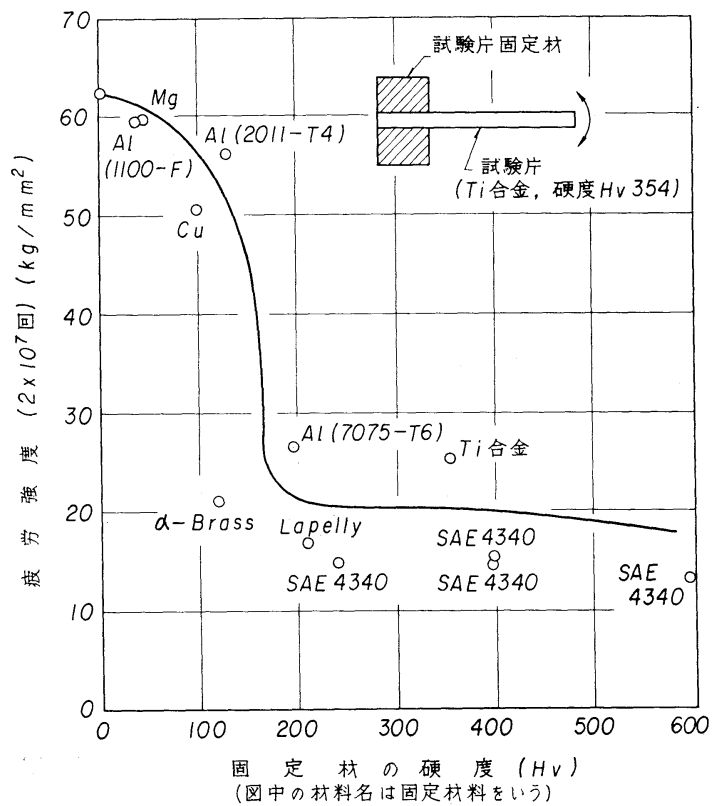

第 1 図固定材の硬度と疲労強度の関係 (7)

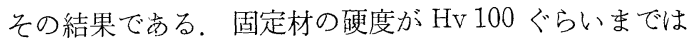

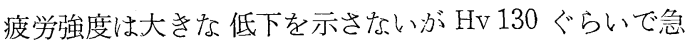
激に低下する。また Corten(8) は $0.4 \%$ 炭素鋼 (硬度 $\mathrm{Hv}$ 392)についても同様の試験を行なつているが, その結果 によると疲労強度の低下割合は固定材がアルミ合金（硬 度 Hv 147)の場合 $9 \%$, 軟鋼 (硬度 Hv 130)の場合 $19 \%$, 真 ちゆ5(硬度 Hv 143) の場合 41\%, 硬鋼 (硬度 Hv 412)の 場合 $50 \%$ である。相手材の硬度が増すと疲労強度の低 下も大さくなりチタン合金で得られた結果と同様の傾向 を持つている。

摩耗粉の硬度の影響については摩耗粉が硬い方が軟い 場合よりも大きな被害を与えると考兄られるが，チタン

(7) H.W.Liu, H.T.Corten and G.M.Sinclair: Proc. ASTM, 57 (1957), 623.

(8) H. T. Corten : Department of Theoretical and Applied Mechanics Univ. of Illinois, Tech. Rep. No. 46 (1955) .
合金についての結果も, また炭素鋼についての結果も固 定材がアルミ合金の場合 (摩耗粉は $\mathrm{Al}_{2} \mathrm{O}_{3}$ ) の方が真ちゆ うの場合 (摩耗粉は $\mathrm{ZnO}$ ) よりも疲労強度の低下量が小さ い. Fennerら (4)の fretting wear に関する実験結果で, 摩 耗粉の効果が認められないことはすべり振巾が小さいこ とに原因しているという理由があげられるが，この場合 にはそのような説明はされ得ない。試験片固定端でのす ベり振巾や応力集中係数は固定部分の剛性, 固定材のヤ ング率，加工硬化のすすみ具合いなどによつて影響され るため異種金属同志の組合わせの場合には fretting によ る被害は材料や摩耗粉の硬度だけで解釈され得ふいで市 ろ5。しかしながら一般摩耗で硬度と耐摩耗性に関する 研究が系統的に行なわれ, ある程度の成功も招さめてい ること, 硬度から一般の疲労強度を推定することがしば しば行なわれていることなどを考劣ると，実用上の立場 にたてば硬度と frettingによる被宫との関係は非常に重 要であり今後の研究が扣执いに期待されるわけである.

\section{(2) 振 動 数の 影 響}

大気中での fretting には酸化という化学作用が伴なら ので,振動数 $(\mathrm{cpm})$ と関係があるのではないかといら推察 はできよう。Uhlig(9) は簡単なモデルから fretting wear による摩耗量は振動数に逆比例して増すことを数式計算 で示した (後述). 彼の試験結果は振動数が $238 \mathrm{cpm}$ 以上 では計算結果とよく一致している. $238 \mathrm{cpm}$ 以下で一致 してないのは $\log (1+x) \approx x$ なる近似が成立しないため であり,他の要因（たとえば接触応力，すべり振巾たど）を かえて $x \ll 1$ となるような条件にすれば, 振動数が低い 範囲でも摩耗量は振動数に逆比例するのではないかと述 ベている.また Feng と Uhlig(10)の試験結果によると 500 cpm 以下では振動数が低いほど摩耗量は多いが $500 \mathrm{cpm}$ 以上ではほとんど変化しない.同様に McDowell(11)も850 cpm 以上では振動数依存性を認めて拉らず, Uhlig の結 果から判断すると $1000 \mathrm{cpm}$ 程度以上の振動数になると, ほとんど振動数には依存しなくなると考えられる.Uhlig らの試験方法は面接触であるが，点接触で行なつた曾田 と青木 (12)もUhlig の結果と同じ傾向を示して和り,振巾 や接触応力の効果も岕るが振動数を増せば摩耗量は減少 するか，むるいは変化しないと考えてょいであろう。

さて fretting fatigue と振動数との関係であるが，こ れについてはとくに述べるほどのデータは見当たらな

(9) H.H.Uhlig: J.Appl. Mech., 21 (1954) , 401.

(10) I.M.Feng and H.H.Uhlig: J.Appl. Mech., 21 (1954), 395 .

(11) C.Lipson and L.V.Colwell: Handbook of Mechanical Wear, (1961), 236.

(12) 曾田, 青木：日本機械学会論文集 (第 4 部)，25 (1959) , 341 . 
い. 大気中での一般の疲労試験結果によると 600 6000 cpm の振動数範囲では疲労強度に差がないといわれてい るが，真空中 $\left(10^{-2} \sim 10^{-5} \mathrm{mmHg}\right)$ では $3000 \mathrm{cpm}$ と 4500 $\mathrm{cpm}$ とで寿命に差のあることが報告されている(13). frettingwear は大気中では振動数の影響をうけ，窒素ガ ス中 (真空中と同じと考えてよいであろろ) では振動数の 影響がないのであるから ${ }^{(10)}$, 上記の一般の疲労現象とは 逆の傾向を持つている. fretting fatigue は摩耗と疲労亀 裂が相伴なつて生ずるわけであり，振動数によつてどの ような影響をうけるか，基礎的な実験としては興味ある 問題でないかと思われる。

\section{(3) すべり振巾の影響}

繰返数, 振動数が一定の場合すべり振巾が大きくなる と, 摩耗量が増すことは多くの試験結果の示すところで ある.傾向としては, Feng と Uhlig( ${ }^{(10)}$ は振巾に比例する といら結果を出して扮り, 伊藤 ${ }^{(3)}$ は振门の 2 乗に比例す るという結果を出している. 繰返数, 振動数を一定にして 実験した場合すべり振巾が変わることは平均すべり速度 の変化と, 摩擦距離の変化を伴ならことであるが, 摩耗量 の増加は摩擦距離の増大によるものと考光るのが妥当て あろう。また摩擦距離を一定にしてすべり振巾をかえた 場合には, 静止摩擦の起こる回数が変化し, すべり振巾 が大きくなれば摩耗量は減少するものと考光られる(12),

笵 2 図はすべり振巾をかえて行なつた fretting fatigue に関する片振り引張 疲労試験結果である(14). すべり振 幅が $3 \times 10^{-4}$ in。程度になると疲労強度はほぼ一定とな

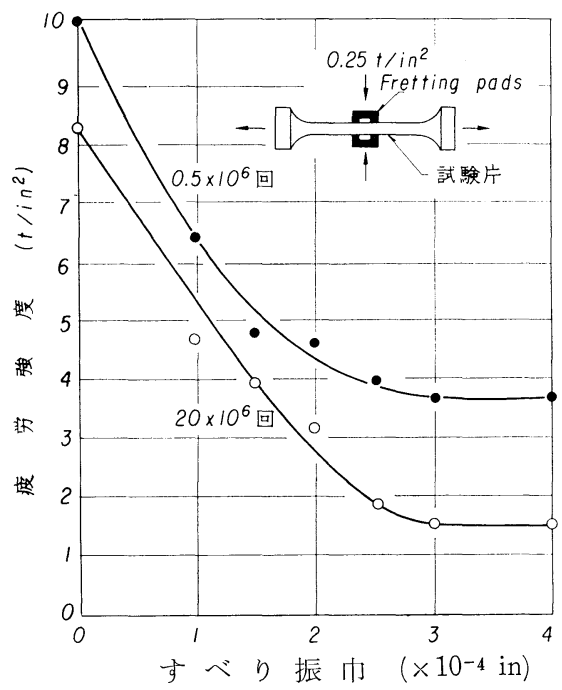

第2図疲労強度とすべり振巾の関係 (14)

(13) H.Shen, S.E.Podlaseck and I.R.Kramer : Acta Met., 14 (1966) , 341.

(14) A.J.Fenner and J.E.Field : Rev. Mét., 55 (1958), 475 .
る. 西岡, 西村特よび平川 ${ }^{(15)}$ が圧入軸のボスと軸部に 生ずる相対すべり振幅の測定を行なつた結果によると軸 径, ボスの外径を一定にすれば, 圧入軸端部の曲げ応力 の 2 乗に注ぼ比例し，たとえば $10 \mathrm{~kg} / \mathrm{mm}^{2}$ の応力で $20 \times$ 10-2 mm のすべり振湢が測定されている(ボス外径 $60 \phi$, 軸径 $50 \phi$ ). 試験方法, 負荷方法が違 ないかもしれないが, 第 2 図の Fenner らの結果と比較 すると非常に大きなすべり振巾であり, 疲労強度がすべ り振巾に汪とんど依存しない範囲に相当する。したがつ てすべり振巾を減少させて(たとえば摩擦力を大きくす るため, しめしろ圧力を大き(する) 疲労強度の増大を はかることはあまり效果がないようにみうけられる。

すべり振けの影響は行なわれた実験の範囲内での結果 では, 明らかな傾向をるつているが，その解釈は fretting の機構との結びつきが，深くむつかしい問題を含んで いる.

\section{（4）接触応力の影響}

接触応力が増すと摩耗量は増加する. 㲘田と青木(12)の 実験結果では摩耗量は荷重の 0.7 乗に比例している。 ま た彼らはFeng らの実験結果も0.7 乗に比例していると 述べ, 計算によつて $2 / 3$ に比例することを導いている. 一. 般摩耗では摩耗機構が一定であるような荷重範团では, 摩耗量は荷重に比例することが知られており, fretting wearによる摩耗が比例しないらしいということは, 興味 ある問題である．接触応力の影響を調べる実験で注意し なければならないことは, 接触応力が増すと摩擦力が大 きくなりその結果すべり振巾が減少することである。す ベり振巾が小さくなると摩耗量が減少することは, すで に述べたが，箔３図はそれを示した Feng と Uhlig の実 験結果である．接触応力が $5 \times 10^{3} \mathrm{psi}$ 以上になると，す ベり振巾の減少が大さく作用して摩耗量が少なくなつて いる.

つぎに fretting fatigue と接触応力の関係について述べ る,第4 図は Liu, Corten および Sinclair(7)の実験結果で 㐫る。試験片はチタン合金(硬度 Hv 354), 固定材はSAE 4340 鋼（硬度 Hv 397）で試験方法は図中に 示すように 平面曲げ疲労試験である。接触応力が $5 \times 10^{3} \mathrm{psi}$ 程度に なると, 疲労強度は注とんど一定し接触応力には依存し ないとみてよい，同様のことは圧入軸での実験によつて も認められている・たとえば圧入しめしろが $4.4 \mathrm{~kg} / \mathrm{mm}^{2}$ と $26 \mathrm{~kg} / \mathrm{mm}^{2}$ とでは疲労強度に差がない(16). fretting wear と接触応力との関係とは対照的である，また第 4

(15) 西岡, 西村, 平川: 日本機械学会第 44 期全国大 会講演前刷集，No.161 (1966)，85.

(16) M.B.Coyle and S.J.Watson: Proc. Instn. Mech. Engrs, $178(1963 \sim 1964), 147$. 


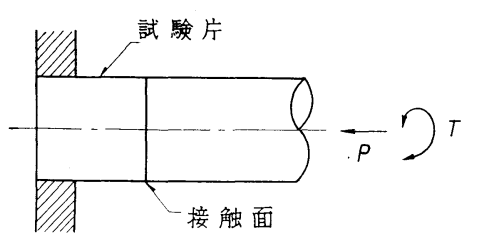

実験方法：トルクTを一定にして, 接触荷重 $\mathrm{P}$ を变数 としてすべり振巾, 摩耗量を測定する。

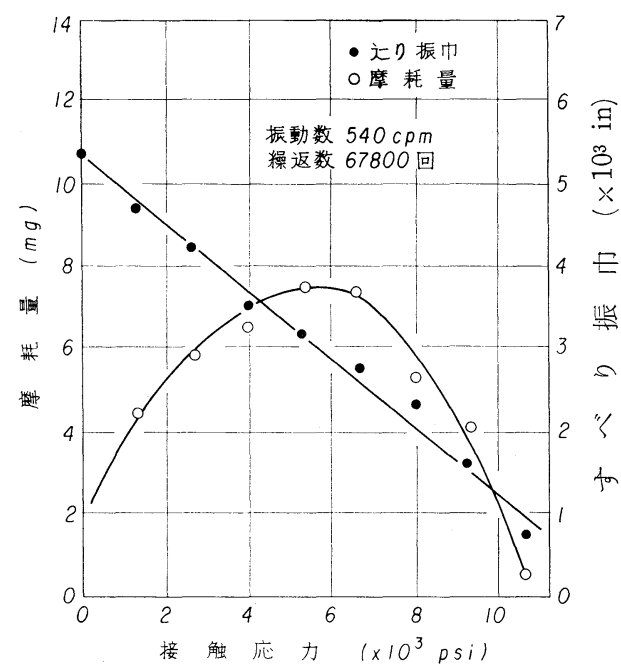

第3 図接触応力と摩耗量, すべり振巾の関係(10)

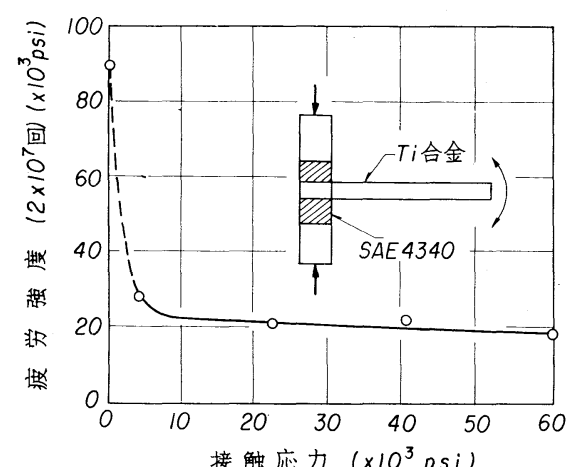

第 4 図接触応力と疲労強度との関係 ${ }^{(7)}$

図は小さな接触応力で大きな疲労強度の低下が生ずるこ とを示しているが，わずかに $15 \mathrm{~g} / \mathrm{mm}^{2}$ の接触応力で約 $25 \%$ 疲労強度が低下した例もある(4).

Harris(17) は接触荷重をいろいろかえてアルミ合金で 据り疲労試験を行なつている。その結果はちようど第 4 図のようにすべり振巾を制御しないで，接触応力を増し た場合に摩耗量の極大值があらえれたように，接触荷重 の増大に伴ない寿命に極小值のあることを認めている. Harris は相手材として鋼, チタン合金についても行な

(17) W.J.Harris: Metallic Fatigue, Pergamon Press, (1961), 161 .
つているが，いずれの場合も寿命の極小となる接触荷重 が存在することを確めている。な拈彼の実験結果では $10^{7}$ 回での疲労強度の低下量は割合にして $27 \%$ 以下で あつた．疲労強度が大きく低下しなかつた理由として彼 は㨝り疲労試験であるがゆえに，切欠き効果があまりな いためであるちと述べている.

以上よりすべり振巾を一定に保てば接触応力が大きく なると摩耗量は増加し, 疲労強度は低下すると考兄てょ い. しかし疲労強度の低下割合は接触応力が小さいとき, はなはだしく接触応力が増して数 $\mathrm{kg} / \mathrm{mm}^{2}$ 程度になれ ば, 疲労強度はほとんど接触応力に依存しなくなる。

\section{(5)䨌囲気の影響}

ここで雾囲気とは，大気中での実験結果と不活性ガス 中, もしくは真空中での実験結果との比較および湿度, 温 度をさしている、箭 5 図, 第 6 図は乾燥大気中, 窒素ガス

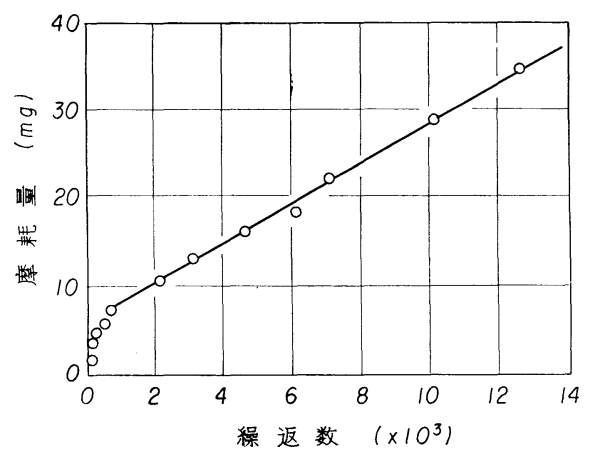

第 5 図乾燥大気中での摩耗量と繰返数の関係(10)

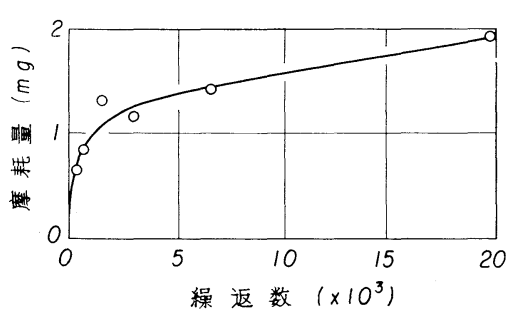

第 6 図 窒素ガス中での摩耗量と繰返数の関係(10) 中で行なつた Feng と Uhlig の実験結果である。両者と もに繰返数が増すにつれ，摩耗量は増加しているが窒素 ガス中での摩耗量は非常に少なく, たとえば $10^{4}$ 回の繰 返数では大気中の約 $1 / 20$ である. 窒素ガス中では振動数 の影響が認められないといら事実も考元ると酸化という 化学作用(もしくは酸素の化学吸着)は fretting wearに大 きな影響を持つことは間違いのない事実のようである。

空気中には水分も含まれて扣り，それによる影響の㐫 ることも知られている。第7図はFeng と Uhlig の実験 結果である。摩耗量は相対湿度にほぼ比例して減少し, 繰返数の多いほど湿度の影響が大きいといえよう。摩耗 


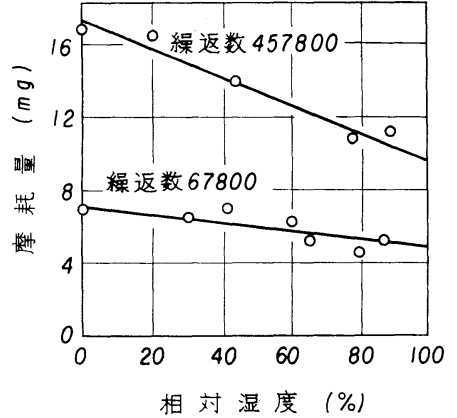

第7図摩耗量と相対温度の関係 ${ }^{(10)}$

量が減少する理由には， $\mathrm{Fe}_{2} \mathrm{O}_{3}$ より $\mathrm{Fe}_{2} \mathrm{O}_{3} \cdot \mathrm{H}_{2} \mathrm{O}$ の方が Mohs 硬度にして約 1 低いため, ざらつき摩耗が隇少す ること, 水分に上る潤滑効果により摩擦係数が小さくな ることがあげられている。しかし半硬鋼で行なつた賏田 と青木 ${ }^{(12)}$ の結果によると, 相対湿度 50 90\%の範囲で は摩耗量は湿度の上昇に伴ない減少しているが, 0 〜 $40 \%$ の湿度範囲では逆に摩耗量が增加している. 約 $40 \%$ の相 対湿度で摩耗量が極大となつたのは水分による腐食性の 摩耗は湿度が増すと増加するが，機械的な摩耗は水分の 潤滑作用で湿度が増すと減少するため, 両者の和である 測定値に極大值が得られたのであるうと述べている.

温度の影響についても Feng(10) らが実験して抒り， $-100^{\circ} \sim 150^{\circ} \mathrm{C}$ の温度範团で温度が上がると摩耗量は減 少している. しかし算田と青木(12)の実験結果では $40^{\circ} \sim$ $100^{\circ} \mathrm{C}$ の温度範囲で摩耗量が 増加している. 温度の変 化には湿度の変化, 摩擦面での酸化速度 (もしくは化学吸 着の割合)の変化が伴ない複雑な結果をもたらすのであ

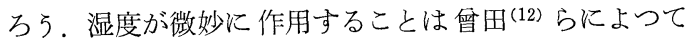
も指摘されている.

つぎに fretting fatigue そついて述べる.チタン合金で 平面曲げ疲労試験を行なつた Liu, Corten 特よび Sinclair の結果によるとアルゴンガス中と大気中とでは fretting fatigue strength け差がない. しかし同じ平面曲げ疲労 試験でも Cr-Ni-Mo 鋼で行なつた Oding と Iwanova(18) の実験によると, 水素ガス中の fretting fatigue strength は大気中のそれより大きく, 両者の疲労強度には差が生 じている.また Fenner と Field(14) は真空中 $\left(10^{-5} \mathrm{mmHg}\right)$ でアルミ合金の fretting fatigue の実験を行なつている が, それによると真空中での疲労強度は $12.5 \pm 2.6 \mathrm{t} / \mathrm{in}^{2}$ であり, 大気中では $12.5 \pm 1.8 \mathrm{t} / \mathrm{in}^{2}$ であつたけ†。一般 の疲労強度は大気中に比べて真空中もしくは不活性ガス

$\dagger$ fretting 条件下での疲労強度のこと。

(18) I. A. Oding and U.S.Iwanova : Int. Conf. on Fatigue of Metals, (1956), 408 .

才† 試験方法は平均応力を $12,5 \mathrm{t} / \mathrm{in}^{2}$ とする片振り引 張疲労試験である。
中では若干高いのが普通であり, また摩耗量が減少する ということから fretting fatigue strength は大気中に比 ベると真空中や不活性ガス中での方が高いと考えてよい と思われる。

さて湿度と fretting fatigue との関係であるが,両者の 間に相関があるといら報告は見当たらない。一般の疲労 強度に対しては材料によつて程度の差はあるが, Bennett ら(19)(20)により湿度が增すと寿命が短くなることが示さ れている。また Bennett(21) は fretting fatigue の実験に おいて子湿度を制御して実験しないと, 結果に大きなば らつきを生ずるであるらと述べている。一般の疲労強度 に対する水分の効果と, 摩耗に対する水分の効果は被害 の点からみると逆であり, fretting fatigue に対しては 湿度は大きな影響を持たないのではないかとす考觉られ る. 雲囲気と fretting fatigue との相互作用に関する系 統的な実験結果が発表されておらず，今後の実験研究に 待つところが多い。

以上で fretting に影響する要因についての記述を終 る. Collins と Marco(22)は fretting 流響する要因は 50 以上あると述べて扔り，以上の活か表面あらさ，摩擦係 数, 負荷方法などの影響について論じた文献もあるが, ここではそれらの引用は省略する(23).

\section{3. fretting の機構について}

摩耗は化学的, 熱的, 機械的作用の共同作用の結果生 ずる現象である. fretting wear は従来の研究から大略 一致して接触部の微小なすべり運動により生ずる摩耗現 象の一つであると考学られている。 また fretting fatigue は摩耗の際生ずる酸化, 摩耗によつて生じた応力集中源 の発生を考学ると，一種の腐食疲労と切欠き疲労の両者 に関連のある疲労現象とみなすともでさよう。以下に fretting の機構を明らかにするためになされた実験, 考 察について述べる.

\section{(1) 摩耗粉について}

発生する摩耗粉について研究することは fretting の機 構を知る上に重要である. 発生した摩耗粉の大きさは, い ろいろデータが発表されて扔り，たとえば $\mathrm{Mg}$ 合金では 約 $1 \mu, \mathrm{Al}$ 合金では $1 \sim 0.05 \mu$, 鋼では $0.01 \mu$ ぐらい,

(19) J.A.Bennett: Material Reserch and Standard, 3 (1963), 480.

(20) T.R.Shives and J.A.Bennett: National Bureau of Standards, CR-267, (1964) .

(21) A. A. Mittenbergs and L.G. Beall, Jr : Proc. ASTM, 62 (1962), 710.

(22) J.A.Collins and S.M.Marco : ASTM, Preprint (1964) .

(23) H.C.Gray and R.W.Jenny : SAE Journal, 52 (1944), 511 . 
硬鋼 では 0.005 0.01 2 という 值が出されている(24). 実験条件，表面あらさによつてる摩耗粉の大きさは異な るが，上の結果からはだいたい母材が硬いほど摩耗粉は 細かくなつている.

大気中で鋼から生ずる 摩耗粉は大別すると $\mathrm{Fe}_{2} \mathrm{O}_{3}$, $\mathrm{Fe}_{3} \mathrm{O}_{4}, \mathrm{Fe}_{2} \mathrm{O}_{3} \cdot \mathrm{H}_{2} \mathrm{O}, \mathrm{Fe}$ であるが摩耗粉の 主成分が $\mathrm{Fe}_{2} \mathrm{O}_{3}$ であることは多くの一致した意見である(17)(24)(25).

摩耗粉に関して解決せねばならぬことは

(1) 室温大気中で鉄が酸化した場 合, $\gamma-\mathrm{Fe}_{2} \mathrm{O}_{3}$ (もしく は $\left.\mathrm{Fe}_{3} \mathrm{O}_{4}\right)$ であるがどのような過程で $\alpha-\mathrm{Fe}_{2} \mathrm{O}_{3}$ となるか，

(2) 摩耗粉はいつ酸化するか, すなわら酸化してから 摩耗粉となるのか, 摩耗粉となつてから酸化するのか, あるいは両者が同時に生じているのか,

(3) 摩耗粉はどのような働さをするのか,

である. (1) で $\gamma-\mathrm{Fe}_{2} \mathrm{O}_{3}$ もしくは $\mathrm{Fe}_{3} \mathrm{O}_{4}$ としたのは, $\mathrm{Fe}_{3} \mathrm{O}_{4}$ から $\alpha-\mathrm{Fe}_{2} \mathrm{O}_{3}$ が生ずる過程について論じている文献と $\gamma-\mathrm{Fe}_{2} \mathrm{O}_{3}$ から $\mathrm{Fe}_{2} \mathrm{O}_{3}$ になる過程について論じている文献 があるため，ここではとくに指定しなかつた。（ $\left(\gamma-\mathrm{Fe}_{2} \mathrm{O}_{3}\right.$ と $\mathrm{Fe}_{3} \mathrm{O}_{4}$ は色, Mohs 硬度が同じであり，格子定数もほ とんど同じであるため同定がかなり困難なようである. $\mathrm{Fe}_{3} \mathrm{O}_{4}$ から $\mathrm{Fe}_{2} \mathrm{O}_{3}$ になると考えるときは $\mathrm{H}_{2} \mathrm{O}$ が重要な役 割をする. $\mathrm{Fe}_{3} \mathrm{O}_{4}$ が $\mathrm{H}_{2} \mathrm{O}$ により $\mathrm{FeO}(\mathrm{OH})$ となり $\left(\mathrm{Fe}_{2} \mathrm{O}_{3}\right.$. $\mathrm{H}_{2} \mathrm{O}$ と同じとみなせる)，最終的にココアと呼ばれる赤 かつ色の $\mathrm{Fe}_{2} \mathrm{O}_{3}$ になるというのである。したがつて乾燥 した空気もしくは酸素内で fretting を生じさせてもココ アは発生しない.

(2) の問題であるが意見が一致して打らず, Tomlinson (26)や Godfrey ら (27) は摩耗粉となつてから酸化するとい う立場をとつている。Fink(28) は大きな圧力のもとでは $4 \mathrm{Fe}+3 \mathrm{O}_{2} \rightarrow 2 \mathrm{Fe}_{2} \mathrm{O}_{3}$ なる反応が促進されると考光, こ れを $\mathrm{Fe}_{2} \mathrm{O}_{3}$ の発生理由としているが，このことは酸化し てから摩耗粉となることを意味していると考えられる. Uhlig ${ }^{(9)}$ は酸化膜の虽離による摩耗粉の発生と機械的な 摩耗で生じた金属粒子がこすられて酸化するという考光 にたつている.

金属の表面酸化の現象は内部の格子欠陷，とくに空孔 の助けによつて進行するが，微粒子の状態になると原子 空孔濃度が高くなり, 大きな結晶に比べて表面積が増し たという以上に酸化速度は大きくなる。したがつてどち らが先といらょり, 酸化摩耗粉も金属粒子も同時に生じ ていると考えてさしつかえないと思われる。

(24) P.L.Teed: Metallurgical Rev., 5 (1960),267.

(25) R.B.Waterhouse: J.Iron Steel Inst., (1961), 301.

(26) G.A.Tomlinson, P.L.Thorpe and H.J.Gough: Proc. Instn. Mech. Engrs., 141 (1931) ,223.

(27) D.Godfrey : NACA Tech. Note, No.2039 (1950).

(28) M.Fink : Trans. Am. Soc. Steel. Treating, (1930), 1026 .
Feng と Rightmire(29) は酸化摩耗粉による pit 形成に ついて論じているが，(3)の摩耗粉の働きに関する問題 もやつかいである，2.の(1)で少し触れたよ5に摩耗粉 の硬度や，その他の物理的性質を考慮しただけでは解決 できない問題がある。

\section{(2)接触面の温度について}

Waterhouse(25)はX線回折により fretting の生じた 部 分が再結晶していることを確め, fretting を生じていな い同一材料をいろいろな温度で焼鈍して，X線回折像が fretting の生じた部分のそれと一致するような焼鈍温度 を求めて，接触面間に発生している温度は $450^{\circ} \sim 550^{\circ} \mathrm{C}$ であると判断した。また彼は軟鋼を大気中で酸化させる と $\gamma-\mathrm{Fe}_{2} \mathrm{O}_{3}$ であるが発生した摩耗粉は $\alpha-\mathrm{Fe}_{2} \mathrm{O}_{3}$ であるこ とからも接触面の温度は $500^{\circ} \mathrm{C} く$ くいには達している と考光た。

Wright(29) は $\mathrm{FeO}$ が検出されていること, $\mathrm{Fe}+\mathrm{Fe}_{3} \mathrm{O}_{4} \rightarrow$ $4 \mathrm{FeO}$ なる反応が起こる臨界温度が $570^{\circ} \mathrm{C}$ であることか ら, この程度の温度は発生しているはずであると述べて いる. Dies(5) もまた鋼対鋼で $\mathrm{FeO}$ や窒化物の生ずるこ と,アルミ合金ではコランダムの生ずることから, 局所的

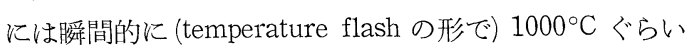
になつているであらうと考えた。

以上は接蜰面の局部的な温度上昇により酸化が促進さ れるという考方方であり，接触面での温度はすべり速度 の小さい割には高いと考えてよいようである。

\section{(3) Fretting damageに関する理論 またはクリテリア}

\section{(i) fretting wear}

古くは Tomlinson(30)の分子摩耗説 (Molecular attrition theory) があるが，発生する摩耗粉の大きさは分子の大 きさ程度ではなく, 実験的な裏付けに之しいようである。 Halliday と Hirst(31) は一種の塑性流動により 酸化膜が 㔀離した後，金属面に凝着が生じ自由摩耗粉がでさこ れが酸化してざらつき摩耗に移行すると考えた。

fretting wear が接触応力, すべり振巾, 振動数などに よつてどのような影響をうけるか 2 .で述べたが, Uhlig (9) は簡単なモデルをもとにして数式計算を行ない，実験 結果をうまく説明した。彼は摩耗が化学的な作用による 摩耗と凝着型の機械的摩耗の和よりなると考えた。前者 は振動数に逆比例し, 後者は振巾に比例する. 結果を式 で示すと

(29) K.H.R.Wright : Proc. Instn. Mech. Engrs., (1952) , 556

(30) G.A.Tomlinson: Proc. Roy. Soc., A, 115 (1927), 472 .

(31) J.S.Halliday and W.Hirst : Proc. Roy. Soc., A, $236(1956), 411$. 


$$
W=\left(k_{0} L^{1 / 2}-k_{1} L\right) \frac{C}{f}+k_{2} l L C
$$

ただし $W:$ 摩耗量

$L:$ 接触応力

$C:$ 繰返数

$f:$ 振動数

$l$ : すべり振巾

$k_{0}, k_{1}, k_{2}$ : 定数

となる。 (1)式では $S \gg 2$ lft なる条件を必要とする(第 8 図参照)。ここで $S$ は asperity 間の 距離, $t$ は酸化が

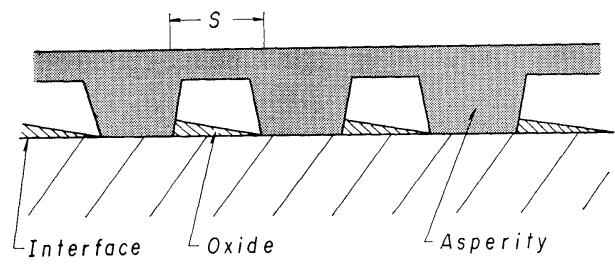

第 8 図接触面のモデル(10)

対数酸化法則に従うと仮定したときに出てくる定数で需 る. (1) 式より真空中, 不活性 ガス中あるいは窒素ガス 中では fretting wear による摩耗量は少なく，振動数の 影響のないこと，大気中では振動数に逆比例することな どがわかる. Uhlig のい5化学作用は酸化を対象として いるから温度があがれば酸化速度が大きくなり, 摩耗量 も増すはずであるが，彼の実験結果は温度が上昇すると 摩耗量は少なくなつている。この矛盾を説明するため Uhlig は機械的な摩耗は温度が上がると減少すること, 酸化ではなく化学吸着ではないかということをあげてい ๖.

機械的作用と化学的作用とが互いに独立して働き, 相 互作用はないものとして計算を行なつているが，これが はたして正しいか，西るいは近似でさることかというこ とは問題である。しかし複雑な摩耗現象を簡単なモデル をもとにして説明を試み, 彼の実験結果に関するかぎり かなり成功しているのは意義のあることであろう。

\section{(ii) fretting fatigue}

Oding と Iwanova(18) は疲労亀裂発生の機構が格子点 に発生した空孔の凝縮 (condensation) にあるという考觉 をむとにして，fretting 条件下では接触部のアノード側 からカソード側へ原子が移動し，空孔が内部へ拡散して 亀裂が発生するという electric erosion mechanism を提 案した。繰返応力によつて空孔が発生することはいろい ろな実験事実（析出や拡散が促進されること，繰返応力 による硬化は静的引張りによる硬化よりも温度依存性の 大きいことなど)から確められているが, 彼らは electric erosion mechanism によつても空孔が発生すると考え た。この機構によつて疲労強度が低下したことを確める
ため, 熱電流と逆方向に電流を流して疲労試験をしたと ころ, fretting fatigue strength は本来の疲労強度と同程 度になつたと報告している，しかし接触面の電位差程度 で原子が亀裂発生の原因となるほどに移動するとは考え 難いこと，第1図で示したような大きな疲労強度の低下 を説明できないことなどの問題があり, electric erosion が fretting fatigue のすべてではないと思われる(17).

Liu, Corten および Sinclair(7) の案験結果はすでに何 度も引用したが, 彼らはつぎの上うな考え方で穾験結果 を整理している。 asperity に動く応力は，曲げによる応 力(試験は平面曲げ疲労試験) と摩擦力による応力の和で あるが，両者の和が材料の疲労強度に達したとき材料は 破壊もしくは亀裂が発生するという考学である，彼らの 得た式は

$$
\sigma_{\mathrm{alt}}=\sqrt{\sigma_{0}{ }^{2}-\frac{1.04 \times 10^{5} \mu^{2} H^{2}}{0.151+\mu^{2}}}
$$

$$
\begin{aligned}
\sigma_{\mathrm{alt}} & : \text { fretting fatigue strength (psi) } \\
\sigma_{0} & : \text { 本来の疲労強度 }(\mathrm{psi}) \\
H & : \text { 固定材の硬度 }(\mathrm{Hv}) \\
\mu & : \text { 摩擦係数 }
\end{aligned}
$$

(2) 式は摩擦係数があまり小さいと成立しないが, 0.2 以 上であれば近似的に成り立つ，彼らによれば固定材の硬 度が Hv 200〜240 ぐらいまでは (2) 式により 疲労強度を 求めることがでさ，それ以上の硬度になると硬度の増大 に伴ないゆるやかに減少する直線で, 硬度と疲労強度の 関係が与えられる. (2) 式であらわされる硬度と疲労強度 の関係が成立する領域と，直線であらわされる領域とで は破壞の様式が異なり, 前者では裂の発生応力が疲労 強度となり, 後者では亀裂が伝播する応力が疲労強度と なる。ことばをかえれば第 9 図で斜線の部分は停留亀裂 の発生する領域といえる。(2) 式を書きかえて 無次元化

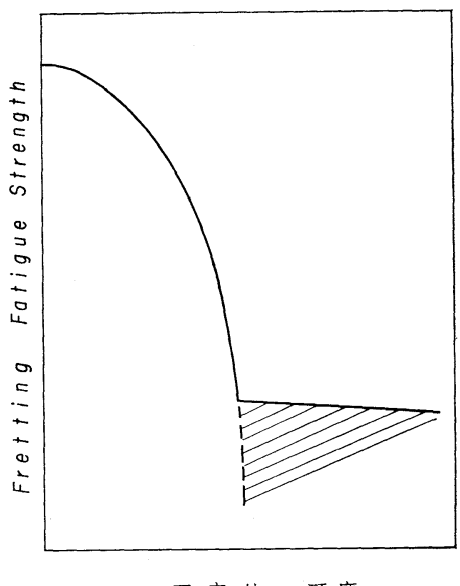

第 9 図 固定材の硬度と fretting fatigue strength の関係 ${ }^{(7)}$ 
すると,鋼の試験片で得られた結果も,チタン合金につい て得られた曲線上に滦滦のることを彼らは示している。 な特彼らは，接触応力がある程度以上の大きさになる と fretting fatigue strength が核とんど一定になるのは, asperity に発生する摩擦力が圧縮応力に依存しないため であると述べている。

以上に fretting wear, fretting fatigue の機構を知る 上に参考となると思われることを述べた。

fretting は機械的な作用と化学的な作用とが共同して 作用する現象である。 fretting wear に上る摩耗量は機 械的な作用のみのもとでは少なく化学的な作用が摩耗を 促進し摩耗に大きな影響をもつている。では, fretting fatigue に対しては化学的な作用はどの 程度影響するか 考えてみ上了。一般の疲労強度に拈上济寸雾囲気の効果 は，亀裂の発生よりむしろ伝播汶対する効果のほうが大 きいといわれている(20)(32)。これは亀裂(ここでいら亀裂 はいわゆる incipient $\operatorname{crack}^{(33)}$ ) の発生時期は真空中でも 大気中でも大差がないといら事実に基づいて招り，伝播

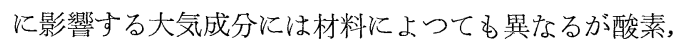
水分があげられている。この説明には格子欠陷論に基つ” いて入り込み(intrusion)が酸素を内部へ持ちこみ，それ が転位の運動に対する障害となるという考え方 ${ }^{(33)}$ や, 亀 裂の再結合 (rebonding) を酸素が妨げるために伝播が促 進されるといら考方方で試みられている(34). fretting 条 件下では摩擦熱汇上る酸化の促進, 接触面が負荷状態に あるために腐食効果の増大ということも考学られないこ とはない。

しかし疲労亀裂の伝播に対する酸素の効果は分圧にし て， 10-3 $\mathrm{mmHg}$ 程度で飽和するという実験結果もあり， 酸素が多く入れば寿命が短くなるとい5 根拠むない。 Fenner と Field(14) の用いたアルミ合金の真空中での疲 労強度が大気中に比べて $5 \%$ 大であると考光ると, 真空 中での fretting fatigue による疲労強度の低下量は 70\%, 大気中での fretting fatigue による低下量は78\%であ る、両者の差は $8 \%$ にすぎない. また Liu, Corten および Sinclair(7)が化学的な作用を考慮することなく話しをす すめても，十分に実験結果を説明できたことをもあわせ て考光ると，大気中での一般の疲労強度と大気中での fretting fatigue strength を比較し論ずる限り，化学的作 用は 2 次的なるのとして考察をすすめてもよいと考光ら れる。

(32) N.J.Wadsworth: Internal Stress and Fatigue in Metals, (1959), 382 .

(33) F.E.Fujita: Fracture of Solid, John Wiley \& Sons, New York, (1963) ,657.

(34) F.J.Bradshaw and C. Wheeler: Applied Materials Research, (1966), 112 .
つぎにどのような物理的原因で疲労強度が低下するか 簡単侤考えてみる。 二面が接触しているとき真実接触面 は荷重によつて大きくかわるが見かけの接触面積よりか なり小さく asperityによつてささえられている. asperity に発生している応力は降伏応力に等しく, asperity は塑性域に竹る。この状態に表面接線力が働けば金属の 表面にできている酸化膜は容易に破断し, 真実接触面積 は増し, 摩擦係数の非常に大凝着摩耗状態となる。 そして表面酸化膜あるいは大気中の酸素, 窒素などの作 用によつて自由摩耗粉が発生し，酸化して酸化摩耗粉と なる。その後摩擦係数が減少する。乙摩耗粉が軟けれ ば固体潤滑剂としての効果す期待できるが, 多くの場合, 硬くしか子体積が膨脹するため pit の形成が促進される あのと考光られる。 このように fretting fatigue によつ て材料が破断汇至るまで㠜着摩耗状態,ざらつき摩耗 状態揖よび両者の中間にそれらの共存する状態が存在す る。

まずざらつき摩耗状態について検討しょう。もしざら つき摩耗状態が寿命に大きな影響をもつならば表面の損 傷度, すなわち摩耗量と寿命の間に相関関係があると考 觉られるが，そのような相関が得られたという報告はな いよらである。これは fretting fatigue, fretting wear が 多くの要因影響されるため, 本来両者の間に相関のあ るべきものが，適格に実験結果を解釈し得ないことが原 因しているか子しれない。しかしつぎの事実も市る。 Fenner と Field ${ }^{(14)}$ が片振り引張疲労試験を fretting 条件 下で行なつた結果によると, fretting による効果は寿命の $1 / 5$ 程度で完全に進行した状態となり,それ以後は fretting 条件下で実験しょうと, 一般の疲労試験の条件下で 実験しょらと全寿命はかわらない。をた第 2 図に示した 上らにすべり振巾がある程度以上の大きされなると, 疲 労強度が一定になるといらことはつぎのようにも解釈で きよう，繰返数が同じで劣るから，すべり振巾が大きく なることは摩擦距離が大きくなることを意味して扔り， ざらつき摩耗状態への移行がはやいと考光られる。なす わち第 2 図の結果は摩擦距離がある程度以上の大きさに なると, 疲労強度低下の要因による効果は, 飽和するこ とを示していると考㝋ることができる、また Hallidary と Hirst (31) は摩擦係数が減少し一定となる程度の繰返数 の後に, 初期に生じていた最大の深さの pit の深さと, 平均の pit 深さとの差が減少し, 摩耗面がいわばならさ れた状態になるのを認めている。このことは初期に発 生した深い pit に上る切欠さ効果が繰返数を增すと減少 する傾向にあり, fretting fatigue, fretting wear との間 の相関関係が小さいことを示していると考光られる. 以上の事実から判断して摩耗後期の状態は寿命低下の 
特もな物理的要因としては除外されると推察される。

つぎに摩擦係数の大きい初期の凝着状態について考え てみる、材料や試験条件によつても違うが，この状態は 時間的にかなり短いようである。たと竞ば Halliday(31) らの結果によると 3000 回以下 (1 分以下), Godfrey らの 結果によるとわずかに 100 回程度 (20 分)である.この程 度の繰返数は Bethune と Waterhouse(35) の求めた fretting fatigue limit†をはるかに下まわる繰返数であるた め, 摩擦係数の大きい凝着摩耗状態での繰返数では, 寿命 がで大きく低下するほどの被害はうけないと考えてよい あろろ。また切欠き試験片の S-N 曲線と fretting 条件 下での平滑試験片の S-N 曲線とが交叉し, その交叉する 繰返数が $10^{5}$ 回以上であるという実験結果からも frettingによつて, 寿命低下が生ずるにはかなりの繰返数を 必要とするものと考学られる. 以上より摩擦係数の大き い凝着摩耗状態のみの繰返数では, 寿命を左右するほど の被害は生ぜず, また後期のざらつき摩耗状態も大きな 影響をもたないと判断される。

したがつて被害が生ずるのは共存状態に至らねばなら ず共存状態が完了するまでには被害は十分進展するとい つてよいと考兄られる. 初期の凝着摩耗状態は 1 サイク ルあたりの被害は最も大きいにもかかわらず，その期間 が短いため被害は寿命に影響するほど進展しないが, 摩 擦係数の小さいざらつき摩耗と凝着摩耗の共存状態はか なり長いため十分な被害を生ずるのであるう。すなわち 共存状態に扣ける亀裂の発生と伝播を促進する物理的要 因を考察することが fretting fatigue の機構を知る手が かりとなると思われる，とくに後期のざらつき摩耗状態 は大きな影響を持たないことから凝着現象において生ず る被害に主眼を持けばよいと推察される。被害を生ぜし める要因としては表面せん断応力による表面の疲労, 発 生した摩擦熱による顕微鏡組織の変化や引張残留応力の 発生, 摩耗粉の作用による亀裂の伝播促進効果, 表面層 の強加工による転位密度の増大, 亀裂の結合などで生じ た pitの切欠き効果などがあげられる、今後の実験研究 により,これらの要因がどの程度の効果を持つか具体的 に示されるものと思う。

\section{Fretting による被害の 防止方法について}

(35) B. Bethune and R.B. Waterhouse: Wear., 8 (1965), 22 .

†ある繰返数だけ fretting 条件下で疲労試験を行な い，その後一般の疲労試験を行ない寿命を求める という実験方法で, 縦軸に fretting 条件下での繰 返数, 横軸に寿命をとると,曲線が横軸に平行とな る fretting 条件下での繰返数がある。その繰返数 を Bethune らは fretting fatigue limit いる. fretting は接触面の往復すべり運動に起因して括り, その程度が雾囲気によつて助長されているのであるか ら, frettingによる被害を少なくするにはすべり運動を なくすればよい。しかし実際問題としてそれができるの は非常に限られるであろう。ぬたすべり振巾を小さくす るという意味で接触面の摩擦係数を大きくしたり，接触 面積を小さくして接触応力を大きくする方法も考えられ るが，この種の方法は被害を大きくする要素を含んでい るので危険性を伴なう。

接触面では初期に凝着が生じ, 続いて摩耗粉が発生し 摩耗が進行していくものと考兄られている。したがつて 相接する二つの金属の化学成分, 拡散係数, 表面エネルギ 一などの化学的, 物理的性質を考虑し固溶体をつくりや すいかどらか検討し凝着を防止することも摩耗による被 害を少なくする方法の一つである，具体的にい壳ば硬い 材料の使用が望ましいわけで，耐摩耗性を有する表面処 理加工，たとえば高周波焼入れ，浸硫処理，浸炭焼入れな どが適当である。またこれらの表面処理の結果, 耐摩耗 性と同時に表面に圧縮残留応力も発生するため fretting fatigue により発生した亀裂の伝播が妨げられ, 結果と して疲労強度が向上することにもなる。この点では表面 の硬度はとくに䯩くはならないが，压縮残留応力を生じ させるショットピーニング, 表面ロールなどの加工も fretting fatigue による被害の防止方法としては良好であ ると判断される。たとえば圧入軸の例をとれば中村, 星 野特よび高橋 ${ }^{(36)}$ は高周波焼入れすることによつて, 回転 曲げ疲労強度が 3〜5 倍, Thum とWunderlich(37) は浸 炭焼入れによつて 3〜5倍, 窒化によつて 3.6 倍という結 果を出している．攵の他へリコプターに使用するピンジ ョイントの疲労強度がショットピーニング, 表面ロール によつて 15３00\% 増大したという結果も報告されてい る(38). どの処理方法, 加工方法が最も適当であるかは 生産性, コスト，使用材料などをよく検討し決定せねね゙ ならない。

発生した摩耗粉による被害を少なくするという意味で は, 硬い摩耗粉を発生する材料の使用を避ける方法も考 えられる、これには接触面に合成樹脂などをそう入した り，メッキをする方法があげられる。メッキの効果につ いては多くの人によつて調べられているが Waterhouse, Brook 牤よび Lee(39)によると熱伝導率が大きく，メッキ

(36) 中村, 星野, 高橋：日本機械学会論文集(第 1 部), 31 (1965), 1147 .

(37) R.B.Heywood: Designing against Fatigue,(1962), Chapman and Hall LTD. London.

(38) K.T.Waters: ASTM, Spec. Tech. Pub. No. $274(1959), 99$.

(39) R.B.Waterhouse, P.A.Brook and G.M.C.Lee: Wear., 5 (1962) , 235. 
厚さが擪く，しかも軟い材料でメッキすることにより fretting の被害を少なくすることができる，たと光ば銀 や銅メッキがよく, Ni や Crの上うに硬くて熱伝導率 の小さい, しかも引張残留応力を発生するメッキ材料は, fretting fatigue による被害を軽減する効果はないといえ よう。メッキしたり合成樹脂をそう入する方法は繰返 数, 応力によつて効果が大きく違うことに注意する必要 がある。

潤滑剂を用いて被贯を軽減させる方法も考えられ, 効 果のある場合もあることが実験結果に示されている(40) (41).潤滑剤の果たす役割は直接接触する面積をへらすと いらより，むしろ酸素に対するしやいいであるという意 見もあるが，メッキと同様繰返数によつて大きくかわ り，場合によつては潤滑剂としての能力を失うばかりで

(40) J.O.Almen: The Corrosion Handbook, John Wiley \& Sons, New York, (1948), 590.

(41) N.A.Scarlett: Engineering, $25(1960), 425$.
なく，分解して腐食効果をもつよ5になることがあり， 潤滑剂の選定には十分留意しなければならない。

\section{5.お わりに}

fretting に影響する要因の数は非常に多く，個々の要 因をとりあげて記述することは，それらの相互作用のた め適切さを欠いたかもしれないが fretting の機構に関す る実験研究が十分でない現状では，このような記述方法 もやむ抗えないと判断したものである。したがつて発表 された論文のうち，実験者によつて結果が一致しないと 考えられる場合もむるが，それらをすべて記述すること は紙数に制限があるため，実用的な見地にたつてできる 限り割愛した。 また fretting の機構については疲労強度 を低下せしめる物理的要因を列挙し，問題点を提起する にとどまつたが，今後実験研究を行ない諸問題を解決し ていきたいと思う。

( $1 \subseteq 67$ 年 3 月 25 日受理)

\section{特 許 量 報 (2)}

$\diamond$ 昭和 42 年 1 月 25 日公告 : 一 含油性の銅系多孔質要滑部材〔昭 42-1521 港区 オイレ 大工業 $\mathrm{KK}] \quad$ wt $\% \mathrm{Sn} 7 \sim 16, \mathrm{~Pb}<20, \mathrm{Zn}<8, \mathrm{Fe} 2 \sim$ 4, Al 0.001 0.1, P 15 の燐銅 $0.2 \sim 0.5$ 残 $\mathrm{Cu}$.

荷電粒子線蒸着装置 [昭 42-1522 千代田区 K K 日立製 作所]

半導体磁器物質の製造方法〔昭 42-1585 門真市 松下電 器産業 KK J チタン酸 ジリウムにカオリン族の化合物 $0.05 \sim 3.6 \mathrm{wt} \%$ 添加.

フェリ磁性組成物〔昭 42-1586 優先権 主張 1963.7.10 (米国) 米国 ウエスターンエレクトリックカムパニー インコーポレーテッド $\left[\mathrm{Ca}_{3}\right]\left[\mathrm{Fe}_{2}\right]\left[\mathrm{Fe}_{1.5} \mathrm{~V}_{1.5}\right] \mathrm{O}_{12}$.

磁石製造方法 [昭 42-1587 大阪市 山内ゴム工業 K K] 合成ゴムとバリウムフェライトの混和.

低損失管導磁率 亜鉄酸塩 磁性材料 [昭 42-1588 新宿区 日本フェライト工業 KK $\mathrm{K}$ ] $\mathrm{mol} \% \mathrm{NiO} 1$ 15, $\mathrm{MgO} 10$ ～ 30, $\mathrm{CuO}$ 6 16, $\mathrm{ZnO} 15 \sim 30$ 残 $\mathrm{Fe}_{2} \mathrm{O}_{3}$.

高誘電率磁器素体の製造法 [昭 42-1589 京都府 K K 村 田製作所了チタン酸 バリウムにチタン酸ストロンチウ ム，錫酸バリウムなど添加。

$\diamond$ 昭和 42 年 1 月 26 日公告 : -

連結部において材質が連続的に変移する金属材料の製造 方法 [昭 42-1641 大阪市 住友金属工業 K K]

Cu-Fe-Co 系合金の製造法 [昭 42-1644 川崎市 東京芝 浦電気 $\mathrm{K} \mathrm{K}$ ] wt \% Fe 0.1 4, Co 0.1 4 残 $\mathrm{Cu}$ に $\mathrm{Mg}$, $\mathrm{Be}, \mathrm{Zr}$ の 1 種または 2 種以上 $0.002 \sim 0.06$ 添加.

強靱銅合金，快削性強靶銅合金（関連 2 件）[昭 42-1645; 1646 新宿区 シチズン時計 $\mathrm{KK}$ K wt $\% \mathrm{Mn} 10 \sim 40, \mathrm{Ni}$ $10 \sim 40$, Co 0.5 10 残 Cu $V(1) \mathrm{Si} 0.05 \sim 2$, (2) Be 0.05 $\sim 0.5$, Cr $0.2 \sim 3$, Ti $0.05 \sim 2$, Zr $0.02 \sim 1$, In $0.2 \sim 5$, Si
0.05〜2の 1 種 または 2 種 以上含有, さらに Te $0.2 \sim 3$ 添加.

水銀をほとんど含まない高純度セレンの製造方法 (2 件) [昭 42-1647; 1648 港区 日本鉱業 K K]

タングステンと銅とのロウ付け方法 (2 件) [昭 42-1653; 1654 千代田区 K K 日立製作所] $\mathrm{Au}-\mathrm{Sn}$ ハンダを使用 する際に該Wに (1) Au-Co 0.1〜12\%, (2) Au-Ni 0.1〜 20\%の管層をのせる.

爆轟衝撃による 金属管の 接合方法 [昭 42-1655 大阪市 旭化成工業 $\mathrm{K} \mathrm{K}$ ]

鋼の無 スケール火焰加熱法 [昭 42-1721 優先権主張 1963.7 .8 (米国) 米国 ベンジャミンゴッダード八ーモ บ]

金色銅合金〔昭 42-1722 川口市松重 栄〕 wt \% B $0.001 \sim 5$, A1 0.1 10, Ni 0.1 10, Ti 0.1 5, In 0.1 5 , Fe $0.01 \sim 10$ 残 $\mathrm{Cu}$.

連続鋳造装置 ( 2 件) [昭 42-1723；1724 千代田区 K K 日立製作所]

鋳物製品のピンホールを充填する方法 [昭 42-1726 横 浜市 野口雪雄]

$\diamond$ 昭和 42 年 1 月 27 日公告 : -

高透磁率フェライト型磁性材料の製造方法〔昭 42-1815 米国 インターナショナル テレフォン アンドテレグラ フコーポレーション丁 $\quad \mathrm{mol}_{\%} \% \mathrm{Fe}_{2} \mathrm{O}_{3} 49.7 \sim 40.6$, $\mathrm{FeO}$ $0.3 \sim 7.5, \mathrm{MnO} 25 \sim 30$ 残 $\mathrm{ZnO}$.

高導電性高力銅合金 [昭 42-1842 大阪市住友特殊金属 $\mathrm{K}$ $\mathrm{K}] \mathrm{wt} \% \mathrm{Be} 0.6 \sim 1.2$, Ni 3.1 6, Mn 0.01 0.2 残 $\mathrm{Cu}$. 一酸化けい素膜の蝕刻加工法〔昭 42-1843 港区 日本電 気 $\mathrm{K}$ K

金属の化学的溶解法 [昭 42-1844 優先権主張 1963.12.

30 (米国) 米国 アライドケミカルコーポレーション] 酸性過酸化水素溶液で $\mathrm{Cu}$ を処理. 